MacDonald AM, Calow RC, Developing groundwater for secure rural water supplies in Africa. Desalination 248: 546-556

\title{
DEVELOPING GROUNDWATER FOR SECURE RURAL WATER SUPPLIES IN AFRICA
}

\author{
A.M. MacDonald ${ }^{1}$, R.C. Calow ${ }^{2}$ \\ ${ }^{1}$ Hydrogeologist, British Geological Survey, West Mains Road, Edinburgh, EH9 3LA, \\ United Kingdom, email: amm@bgs.ac.uk \\ ${ }^{2}$ Socio-economist, British Geological Survey, Crowmarsh Gifford, Wallingford, OXON, OX10 8BB, \\ United Kingdom
}

\begin{abstract}
In sub-Saharan Africa $85 \%$ of those without access to safe water live in rural areas where the consequent poverty and ill health disproportionately affect women and children. The widespread development of groundwater is the most affordable and sustainable way of improving access to secure water for the rural poor on the scale required to achieve current coverage targets. However, groundwater resources vary considerably across the continent, and the sustainable development of the resource depends on an accurate understanding of the hydrogeology. To develop secure water supplies, the quantity, quality and sustainability of groundwater resources must be known to ensure that key decisions are informed by knowledge of resource conditions. Communities must also be involved at every stage of the process and given the authority to manage and maintain sources. There is a danger that the current pressure to achieve ambitious coverage targets will result in short cuts being taken and, although many new sources are constructed, they will not be secure.
\end{abstract}

Keywords: groundwater; Africa; water supply

\section{Introduction}

In 2004 there were still at least 1100 million people across the world who did not have access to safe, clean drinking water [1]. Many of these people live in rural areas and are among the poorest and most vulnerable to be found anywhere in the world. Without clean water, people's health and livelihoods can be severely affected; children's (particularly girls') education suffers as the daily tasks of survival take precedence over all other concerns. Faced with this depressing reality, the international community has set ambitious Millennium Development Goals (MDGs) to reduce by half the number of people without clean water by 2015 [2].

In this context, the need for sustainable development and management of groundwater cannot be overstated. Across large swathes of Africa, South America and Asia, groundwater provides the only realistic water supply option for meeting dispersed rural demand [3]. Alternative water resources can be unreliable and expensive to develop: surface water (if available) is prone to contamination and often seasonal; rainwater harvesting can be expensive and requires good rainfall throughout the year. Groundwater, however, can be found in most environments. It generally requires no prior treatment since it is naturally protected from contamination; it does not vary significantly seasonally and is often drought resistant. Also it lends itself to the principles of community management - it can be found close to the point of demand and be developed incrementally (and often at low cost). However, the resource is not invulnerable: with the ability to pump out large quantities of water, and the advent of particularly persistent contaminants, the resource needs to be protected and managed. Table 1 summarises the advantages of groundwater for rural water supply, with some qualifications.

In this paper we discuss the groundwater resources in Africa, and the steps required to develop secure rural water supplies.

\section{Groundwater resources in Africa}

Groundwater occurrence depends primarily on geology, geomorphology/weathering and rainfall (both current and historic). The interplay of these three factors gives rise to complex hydrogeological environments with countless variations in the quantity, quality, ease of access and renewability of groundwater resources. 
MacDonald AM, Calow RC, Developing groundwater for secure rural water supplies in Africa. Desalination 248: 546-556

Rainfall is highly variable across Africa. Annual rainfall varies from negligible over parts of the Sahara, to almost $10,000 \mathrm{~mm}$ in the Gulf of Guinea (Figure 1). As a consequence of this great variability, the hydrology of Africa is probably the most variable and challenging of all populated continents demonstrated by the low runoff/rainfall coefficient (0.23) [5]. This illustrates the high evaporation, and low volume of water flowing in rivers. The great variability in rainfall, and in particular the long dry season (>5 months) over much of Africa, increases reliance on groundwater storage for water supply. Recharge to groundwater in wet periods is naturally stored, and can be abstracted in times of drought. There is no simple direct relationship between average annual rainfall and recharge, and significant recharge $(10-50 \mathrm{~mm})$ can still occur where annual rainfall is less than $500 \mathrm{~mm}$ [6][7][8].

\section{Table $1 \quad$ Advantages and limitations of groundwater [4]}

\section{ADVANTAGE OF GROUNDWATER}

Groundwater is often available close to where it is required

Groundwater can be developed relatively cheaply and progressively to meet demand with lower capital investment than many surface water schemes

Groundwater generally has excellent natural quality, and is usually adequate for potable supply with little or no treatment

Groundwater generally has a protective cover provided by the soil and unsaturated zone

\section{QUALIFYING LIMITATIONS}

Considerable effort may be needed in some situations to locate suitable sites

As overall coverage increases, the more difficult areas which are left can become more costly to supply

\section{Naturally-occurring quality constraints are becoming more widely observed}

As development increases more rapidly, the threat of pollution from human activities needs to be assessed in relation to the nature of the protective cover

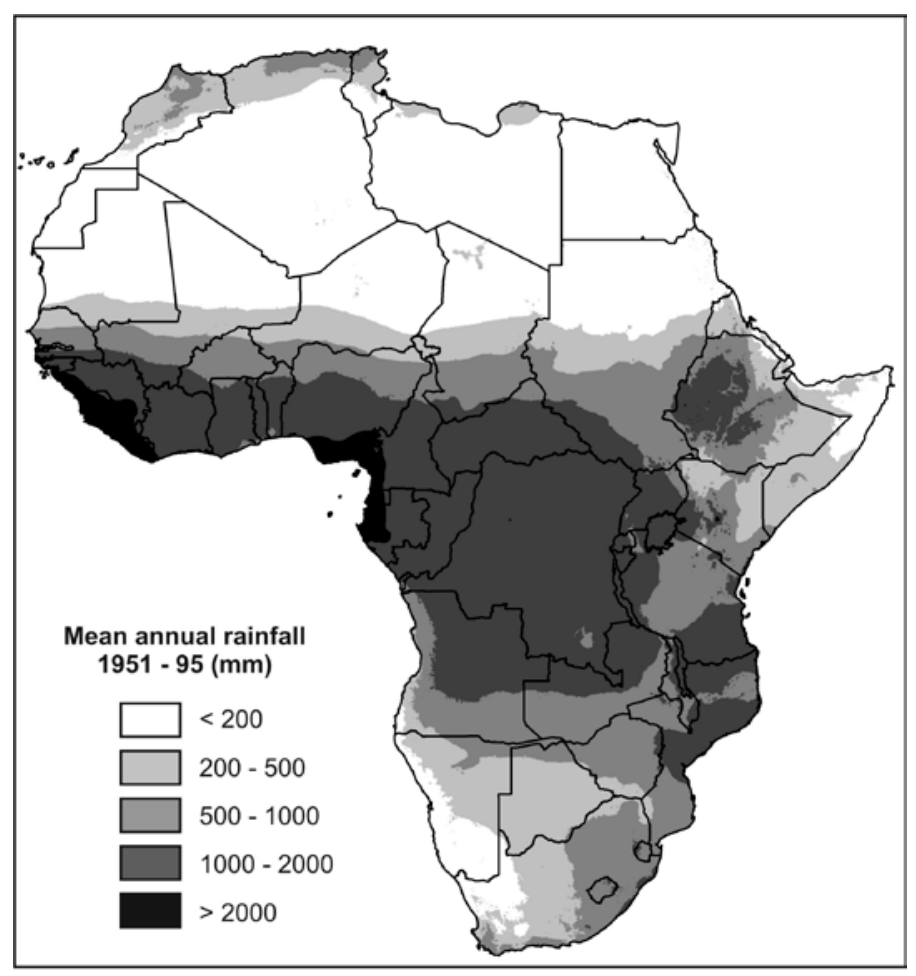

Figure 1. Average annual rainfall for Africa for the period 1951 - 1995 [9] 
MacDonald AM, Calow RC, Developing groundwater for secure rural water supplies in Africa. Desalination 248: 546-556

The available groundwater resources are best described by considering the geology and constructing a hydrogeological map - which classifies the geology into units in which groundwater is likely to occur in a similar way. A simplified hydrogeological map for Africa is shown in Figure 2 based on a synthesis of studies [10][11][12][13][14] and using the 1:5,000,000 scale geological map of Africa as a base [15][16]. The four different environments are: Precambrian "basement" rocks, volcanic rocks, unconsolidated sediments, and consolidated sedimentary rocks. Roughly $34 \%$ of the land surface is underlain by heterogeneous Precambrian basement; $37 \%$ by consolidated sedimentary rocks; $25 \%$ by unconsolidated sediments; and $4 \%$ by volcanic rocks [17]. Groundwater occurrence in each hydrogeological environment is described below and illustrated in Figure 3.

Precambrian basement rocks comprise crystalline igneous and metamorphic rocks over 550 million years old. Unweathered and non-fractured basement rocks contain negligible quantities of groundwater. Significant aquifers however, develop within the weathered overburden and fractured bedrock [18].

Consolidated sedimentary rocks, particularly large sandstone basins, can store considerable volumes of groundwater, but in arid regions, much of the groundwater can be non-renewable, having been recharged when the area received considerably more rainfall. Also, sedimentary rocks are highly variable and can comprise low permeability mudstone and shale as well as more permeable sandstones and limestones [14],[19].

Unconsolidated sediments form some of the most productive aquifers in Africa. They cover approximately $25 \%$ of the land surface of Africa (Figure 2). However, this is probably an underestimate of their true importance since only the thickest and most extensive deposits are shown on the map. Unconsolidated sediments are also present in many river valleys throughout Africa [11].

Volcanic rocks occupy only $4 \%$ of the land area of Africa and are found in east and southern Africa where they can form important aquifer systems. However, despite their small extent, they are highly significant aquifers since they underlie much of the poorest and drought stricken areas of Africa. The groundwater potential of volcanic rocks varies considerably, reflecting the complexity of the geology [20].

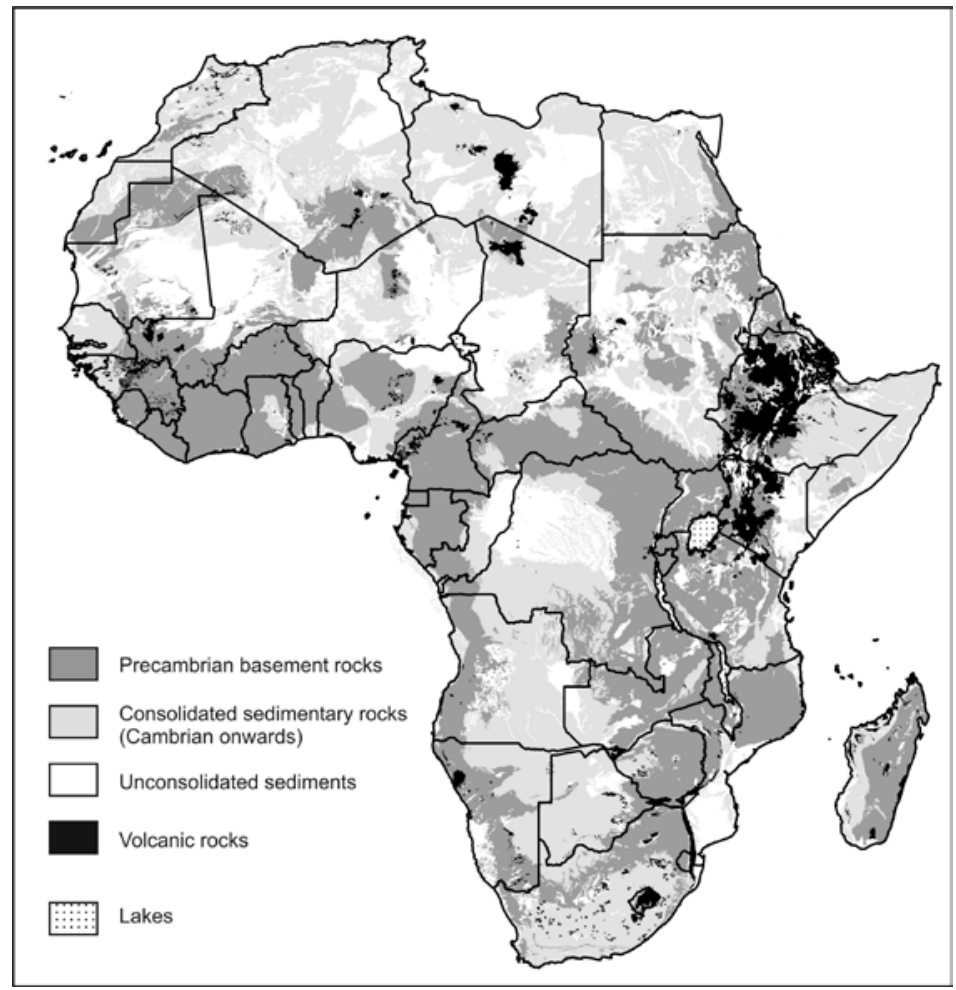


MacDonald AM, Calow RC, Developing groundwater for secure rural water supplies in Africa. Desalination 248: 546-556

Figure 2. The hydrogeological environments of Africa [14]

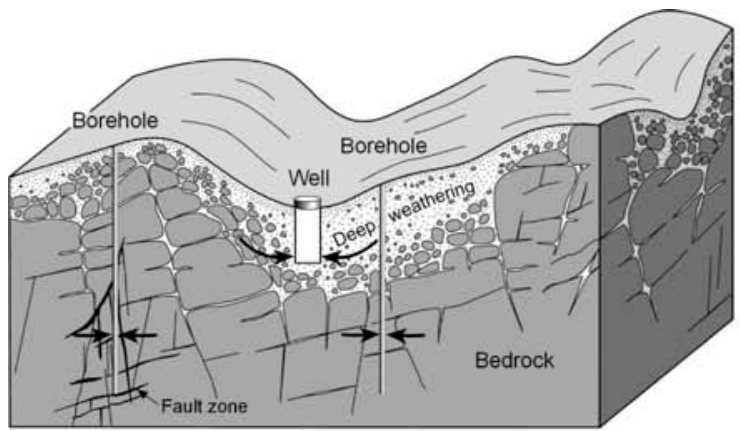

Groundwater occurrence in basement rocks

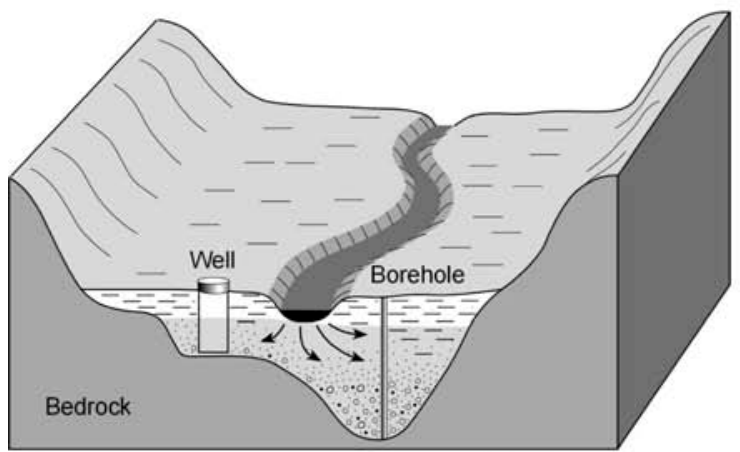

Groundwater occurrence in riverside alluvium

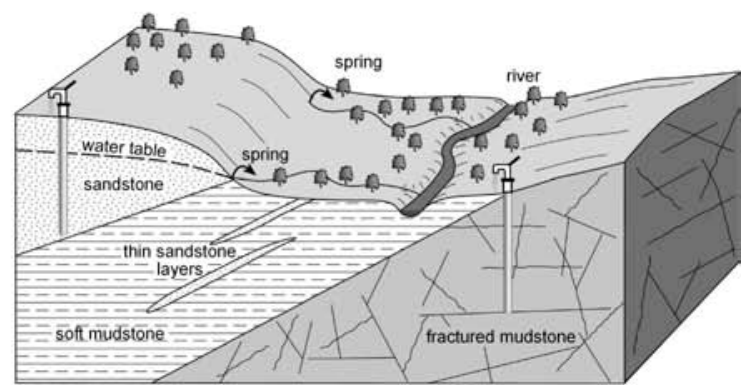

Groundwater occurrence in sedimentary rocks

Figure 3. Groundwater occurrence in different African environments [4]

\section{Developing secure supplies}

Water security is fundamental to eliminating poverty. Only with reliable safe water supplies can households build sustainable livelihoods as time is freed up to concentrate on income generating activities, and water is put to productive uses. Some of the factors that constitute a secure supply are:

- the water is of sufficient quantity to meet all requirements;

- the water is safe to drink and does not represent a health risk;

- the supply is reliable all year round, and also in times of drought, when demand can be high;

- the water is accessible to all in a community and within a reasonable distance of all households (usually within $1 \mathrm{~km}$ )

- the supply is affordable and can be easily maintained.

To achieve a secure groundwater supply the following factors must be incorporated into any rural water supply project or programme.

\section{Boreholes or wells should be sited effectively}

Any groundwater source should be located where the groundwater resources are sufficient and able to meet the demands put upon it. Modest investment in resource assessment and siting techniques can pay dividends in terms of higher drilling success rates and higher yielding (more reliable) sources [4]. Simple tests can also be carried out to assess the performance of a well or borehole once it has been constructed, providing valuable information on how the source will behave during drought [21]. If a single source cannot meet peak dry season or drought demand, further village sources may need to 
MacDonald AM, Calow RC, Developing groundwater for secure rural water supplies in Africa. Desalination 248: 546-556

be developed. In the longer term this is more cost effective than trying to cope with water shortage when drought arrives [22].

In some areas, for example on major alluvial plains with abundant rainfall, groundwater may be widely available at relatively shallow depths. In these areas, little or no hydrogeological investigation is necessary as wells or boreholes may be successful wherever they are developed. Siting can therefore be determined by the local population alone. In environments which are more geologically heterogeneous, however, investigations ranging from simple field observation to more costly exploratory drilling and surveying may be necessary to ensure success (see Table 2). Where investigations help reduce the number of unsuccessful wells drilled, cost savings may be significant, more than covering the cost of the investigation procedure (Figure 4).

Table 2 The costs and benefits of different borehole siting methods

GROUNDWATER

EXPLORATION TECHNIQUE

Reconnaissance

$\tilde{y}$
0
0
0
0
0
0

Hydrogeological fieldwork

Siting using an experienced eye

by examining the rocks and geomorphology in an area

Discussion with local communities

\section{Geophysical surveying :}

Resistivity, Electromagnetic, seismic, etc (see [4] overview)

Must be combined with reconnaissance data and hydrogeological fieldwork

\section{Exploratory drilling}

Drill exploratory boreholes in a community - often combined with hydrogeological fieldwork and geophysics.
COSTS

NOTES

A one off cost - several weeks time of a project member or consultant.

More expensive (but not prohibitively so) if data have to be generated from satellite images, field mapping etc.

$$
\begin{gathered}
\text { Requires a well trained } \\
\text { engineer to visit the } \\
\text { community }
\end{gathered}
$$

Equipment varies in price but is generally < \$US $20 \mathrm{k}$. A well trained geophysics team will need at least 1 day in each community.

Costs equivalent to drilling a dry borehole, but considerably reduced if the team has control over their own rig.

Could be a one off cost if the exploratory drilling leads to better interpretation of geophysics
Objective is to 'groundtruth' results gathered from reconnaissance

\section{Essential first step for understanding the groundwater resources.}

Important to have good analysis of the data. Investment in training staff often beneficial.

The only way to 'prove' that groundwater occurs in an area.

Requires careful facilitation to ensure that communities do not get frustrated by drilling of 'test' boreholes. 
MacDonald AM, Calow RC, Developing groundwater for secure rural water supplies in Africa. Desalination 248: 546-556

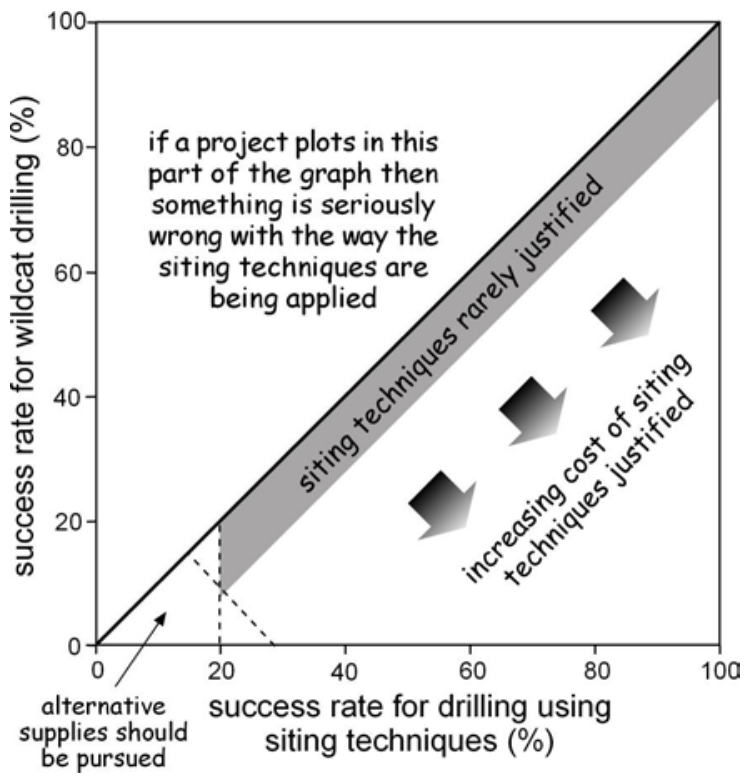

Figure 4. A summary of the circumstances when siting techniques can be economically justified. Wildcat drilling is random drilling using no siting techniques [4].

\section{Maintenance: communities must participate at all stages}

The need for community participation in the planning and implementation of rural water supply projects became increasingly apparent in the 1980s. Governments and donors realised that that they could no longer afford centralised operation and maintenance systems, and that existing top down approaches were not creating sustainable water supply systems. As a consequence, the idea that beneficiaries, or users, needed to be involved with the ongoing maintenance of systems began to be more widely discussed. Hence, ideas about community participation were initially fairly restricted: most attention was focussed on trying to get communities to raise funds to help with the upkeep of their water systems.

Community management in rural water supply, however, goes some way beyond participation. There is no fixed definition or simple formulae, but a key feature is the nature and breadth of decisionmaking, and the responsibility for executing those decisions being more with the community. Community management in rural water supply, as opposed to participation, therefore, implies [23]:

- The community has legitimate authority and effective control over management of the water supply system and over the use of water.

- The community commits resources towards both the implementation and upkeep of the system(s).

- Supporting agencies provide advice and technical support, but key decisions about participation in a project, and about the type, level and location of services, are made with the community.

- Development of people - individual and community empowerment - is a parallel goal. Community management is people-centred: the principal concern is with people's livelihoods, not the resources they use or the technologies employed.

Despite its obvious appeal, however, community management is more complex than might first appear. Community decision-making, for example, does not always reflect the interests of poorer, 
MacDonald AM, Calow RC, Developing groundwater for secure rural water supplies in Africa. Desalination 248: 546-556

more marginalised groups; hence community management does not, in itself, guarantee that the needs of all households are met. Why is this so? A key point is that communities are not homogeneous, in terms of the interests, expectations and power of different individuals to influence community decisions [4]. Care needs to be taken to ensure the needs of all groups - especially women, children and the poor who may have little or no community voice - are factored into decisions on service provision. A project has an important role to play here in making sure that these voices are heard.

\section{Water supplies should be engineered appropriately}

As the provision of rural water supply becomes increasingly decentralised, budget holders (who are often based in district or local government) have little knowledge about the complexities of groundwater investigations and borehole development. This makes it difficult for them to judge whether supplies are engineered appropriately for the terrain [4]. As a consequence, there are many examples of boreholes or wells that have been poorly constructed and stopped working after a short time, or never worked at all. Conversely sources can be over-engineered at great cost,to the detriment of other, unserved communities.

As a general guideline, boreholes should be designed to meet the following criteria:

- borehole efficiency is maximized (high pumping from small diameter boreholes can lead to friction losses and deep drawdowns);

- $\quad$ sand inflow to the borehole is kept to a minimum (this can quickly wear out pumps);

- materials are of sufficient quality to last at least 25 years;

- any contaminated sources or aquifers, or zones of undesirable water quality, should be sealed off from the borehole.

Obviously these factors have to be balanced with the cost of the borehole. Drilling a large diameter borehole to $100 \mathrm{~m}$ and lining it with expensive stainless steel screen could cost as much as ten narrow diameter boreholes drilled to $50 \mathrm{~m}$ and completed with uPVC screen and casing. Also, it is important to know whether the borehole is likely to be successful before installing expensive screen and casing.

There have been recent moves to make borehole drilling more cost effective and fit for purpose [24]. This involves using smaller less costly drilling rigs to drill reduced $(100-150 \mathrm{~mm})$ diameter boreholes completed with plastic screens and casing. These designs, where coupled with a good understanding of the groundwater resources and good siting techniques (see above) can give high quality sources at much reduced cost.

\section{The quality of the water must be known}

Groundwater has traditionally been regarded as having good natural quality. For most of the geological environments this is true, but this does not mean that natural groundwater quality is always good. The natural quality can vary from one rock type to another and also within aquifers along groundwater flow paths. Because groundwater movement can be so slow, and residence times long, there is scope for chemical interaction between the water and the rock material through which it passes. Natural groundwater quality changes start in the soil, where infiltrating rainfall equilibrates with carbon dioxide to produce weak carbonic acid which can remove soluble minerals from the underlying rocks.

Nine major chemical constituents - sodium (Na), calcium (Ca), magnesium (Mg), potassium (K), bicarbonate $\left(\mathrm{HCO}_{3}\right)$, chloride $(\mathrm{Cl})$, sulphate $\left(\mathrm{SO}_{4}\right)$, nitrate $\left(\mathrm{NO}_{3}\right)$ and silicon $(\mathrm{Si})$ - make up about $99 \%$ of the solute content of natural groundwaters. The concentrations of these constituents give groundwaters their hydrochemical characterisation, and the proportions reflect the geological origin and groundwater flow regime [25]. However, it is the presence (or absence) of the remaining 1\% - the 
MacDonald AM, Calow RC, Developing groundwater for secure rural water supplies in Africa. Desalination 248: 546-556

minor and trace elements - that can occasionally give rise to health problems or make the water unacceptable for human use. Figure 5 indicates which chemicals are essential for humans and which are harmful. Of particular concern in East Africa are elevated concentrations of fluoride [26]. Although arsenic has not yet been widely detected, the lack of monitoring does not mean that the problem is absent [25],[27].

To ensure secure water supplies, the quality of the water must be assessed at the time of construction and some method of regular monitoring for a selection of boreholes to identify any degradation. Currently in Africa this does not occur, and without a major incentive from donors or government it is unlikely that thorough groundwater quality monitoring will be taken seriously.

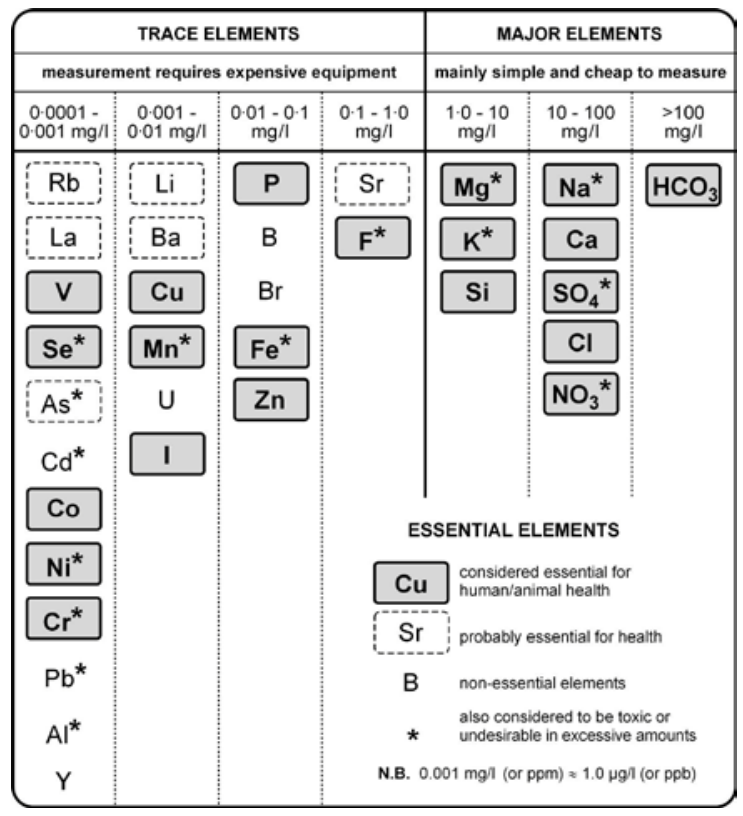

Figure 5. The health effects of different constituents found in groundwater [3][25].

\section{Supplies and groundwater resources must be protected from contamination}

Water quality can deteriorate through contamination of the local groundwater, or direct contamination of the water supply itself. Rural water supplies can be particularly vulnerable since they are often shallow and have hazards close by - such as pit latrines, or animal watering troughs etc. (Figure 6).

To minimise the risk of contamination of the water supply, the supply must be well constructed, and sources of contamination kept away. Community management of a source using simple guidelines can help to keep animals away from a supply and minimised any standing water. Sanitary inspections provide an easy but effective, risk-based approach to monitoring wellhead protection [28]. The use of standardised and quantifiable approaches makes it possible to compare the results obtained by different inspectors, allows an overall risk score to be developed, identifies priority sites for remedial actions and permits comparisons between different supply types.

In rural Africa, the increase in the use and construction of household latrines poses a considerable threat to the groundwater supplies. Contaminants can migrate vertically to the aquifer and then to the borehole, or more dangerously, horizontally through permeable soils to poorly constructed supplies (see Figure 6). Some methods are available to help site latrines an appropriate distance from water supplies to help reduce contamination [29].

Groundwater vulnerable techniques are well developed in most northern countries to help inform land use planning and exclude the most polluting activities from vulnerable aquifers. Such techniques are 
MacDonald AM, Calow RC, Developing groundwater for secure rural water supplies in Africa. Desalination 248: 546-556

difficult to apply on an African context due to a general absence of government legislation enforcement, but some recent efforts at vulnerability mapping are being made [17],[30].

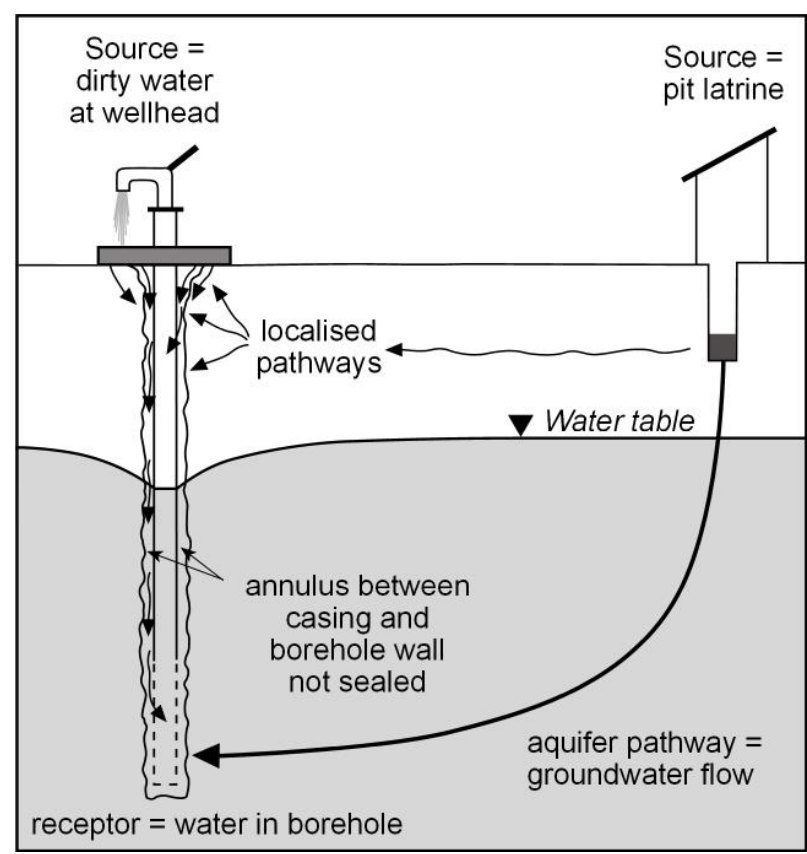

Figure 6. The source $\rightarrow$ pathway $\rightarrow$ receptor concept for groundwater pollution [29]

\section{Conclusions}

Over much of Africa, developing groundwater offers the only realistic and affordable way to meet coverage targets and improve access to water. However, to build secure groundwater supplies takes time. The groundwater resources must be understood, and boreholes/wells developed in a way that is appropriate to the hydrogeology - to ensure long term availability of the water. It is also important to know the quality of the water (to ensure it is fit to drink) and protect the water supply and local groundwater resource from contamination. Equally important as these engineering and resource aspects is the need for community participation in the long term management of the source to enable the source to be maintained for the benefit of all.

The current pressure to reach the targets set out in the Millennium Development Goals, and dramatically increase the rate of borehole construction across Africa may mean that many communities do not get access to secure water supplies. The pressure to meet short term coverage targets will inevitably lead to short cuts in both groundwater resources assessment and the involvement of communities. As a consequence there is a very real danger that although new water supplies are constructed, they will not be secure, and as a consequence soon fail the communities they are meant to serve.

\section{Acknowledgements}

This paper is based on research from a variety of projects, largely funded by the UK Department for International Development (DFID). However, the views expressed are not necessarily those of DFID. This paper is published with the permission of the Executive Director of the British Geological Survey (NERC)

\section{References}

[1] JMP. Global water supply and sanitation 2004 report. Joint Monitoring Programme WHO/UNICEF. World Health Organization: Geneva, 2004. 
MacDonald AM, Calow RC, Developing groundwater for secure rural water supplies in Africa. Desalination 248: 546-556

[2] United Nations. United Nations Millennium Declaration. United Nations General Assembly, A/RES/55/2. United Nations: New York, 2000.

[3] Foster SSD, Chilton PJ, Moench $\mathrm{M}$ et al. Groundwater in rural development. World Bank Technical Paper 463, Washington DC: The World Bank, 2000.

[4] MacDonald AM, Davies J, Calow RC, Chilton, J. Developing groundwater: a guide for rural water supply. ITDG Publishing: Rugby, UK, 2005.

[5] Walling, DE. "Hydrology and rivers", in Adams WM, Goudie AS, Orme AR (ed.): The physical geography of Africa, Oxford University Press: Oxford, UK, 1996,103-121.

[6] Edmunds WM, Gaye CB. Estimating the spatial variability of groundwater recharge in the Sahel using chloride. Journal of Hydrology, 1994; 156: 47-59.

[7] Butterworth JA, Macdonald DMJ, Bromley $\mathrm{J}$ et al. Hydrological processes and water resources management in a dryland environment III: groundwater recharge and recession in a shallow weathered aquifer. Hydrology and Earth System Sciences 1999; 3: 345-352.

[8] Edmunds WM, Fellman E, Goni I et al. Spatial and temporal distribution of groundwater recharge in northern Nigeria. Hydrogeology Journal 2002; 10: 205-215.

[9] New M, Hulme M. A monthly rainfall dataset for Africa for 1951 to 1995 . University of East Anglia: Norwich, 1997.

[10] Foster SSD. "African groundwater development - the challenges for hydrogeological science", in: Challenges in African Hydrology and Water Resources, Proceedings of the Harare symposium, July 1984, IAHS Publication 144, 1984.

[11] Guiraud R. L'hydrogeologie de l'Afrique. Journal of African Earth Sciences 1988; 7: 519-543.

[12] UNTCD. Groundwater in North and West Africa. Natural Resources/Water Series, 18, United Nations: New York, 1988.

[13] UNTCD. Groundwater in Eastern, Central and Southern Africa. Natural Resources/Water Series, 19, United Nations: New York, 1989.

[14] MacDonald AM, Davies J, Calow RC. "African hydrogeology and rural water supply", in Adelana SMA, MacDonald AM (ed.) Applied Groundwater Studies in Africa. International Association of Hydrogeologists, Taylor \& Francis: Amsterdam, 2008.

[15] UNESCO. Africa Geological Map Scale (1:5,000,000). 6 Sheets. UNESCO: Paris, 1991.

[16] Persits F, Ahlbrandt T, Tuttle M et al. Maps showing geology, oil and gas fields and geological provinces of Africa. USGS Open-file report 97-470A, 1997.

[17] Adelana SMA, MacDonald AM (ed.) Applied Groundwater Studies in Africa, IAH Selected Papers on Hydrogeology. Volume 13, CRC Press/Balkema, Leiden, The Netherlands 2008.

[18] Wright E P. "The hydrogeology of crystalline basement aquifers in Africa", in Wright EP, Burgess WG (ed.) The hydrogeology of crystalline basement aquifers in Africa. Geological Society London Special Publications 1992; 66: 1-27.

[19] MacDonald AM, Kemp SJ, Davies J. Transmissivity variations in mudstones. Ground Water 2005; 43: $259-269$.

[20] Demlie M, Wohnlich S, Wisotzky F et al. Groundwater recharge, flow and hydrogeochemical evolution in a complex volcanic aquifer system, central Ethiopia. Hydrogeology Journal 2007; 15: 1169-1181.

[21] MacDonald AM, Barker JA, Davies J. The bailer test: a simple effective pumping test for assessing borehole success. Hydrogeology Journal 2008; DOI: 10.1007/s10040-008-0286-1

[22] Calow RC, MacDonald AM, Nicol AL et al. Groundwater and drought in Africa. Ground Water in press.

[23] UNICEF. Towards better programming: a water handbook. Water, Environment and Sanitation Technical Guidelines Series No 2. UNICEF: New York, 1999. 
MacDonald AM, Calow RC, Developing groundwater for secure rural water supplies in Africa.

Desalination 248: 546-556

[24] Carter RC. Drilling for Water in Ethiopia: 10 Steps to Cost-Effective Boreholes. WSP Field Note, Water and Sanitation Program - Africa, World Bank: Nairobi, 2006.

[25] Edmunds WM, Smedley PL. "Groundwater geochemistry and health: an overview", in Appleton JD, Fuge R, McCall GJH (ed.) Environmental Geochemistry and Health. Geological Society Special Publications 1996; 113: 81-105.

[26] Edmunds WM, Smedley PL. "Fluoride in natural waters", in Essentials of Medical Geology, Elsevier Academic Press 2005: 301-330.

[27] Smedley PL, Kinniburgh DG. A review of the source, behavior and distribution of arsenic in natural waters. Applied Geochemistry 2002; 17: 517-568.

[28] Howard, G, Pedley, S, Barrett, M, et al. Risk factors contributing to microbiological contamination of shallow groundwater in Kampala, Uganda. Water Research 2003; 37: 3421-3429.

[29] ARGOSS. Guidelines for assessing the risk to groundwater from on-site sanitation. British Geological Survey Commissioned Report CR/01/142, 2001.

[30] Robins NS, Chilton PJ, Cobbing JE. Adapting existing experience with aquifer vulnerability and groundwater protection for Africa. Journal of African Earth Science 2007: 47: 30-38. 